\title{
A Frequency Analysis of Selected Modal Express- ions in German and English Legal Texts
}

\begin{abstract}
This paper concerns the specialised use of written English and German in texts relating to contract law. It is based on corpora of original texts and examines specifically the way in which obligation is expressed in the two languages. The text types on which the present analysis is based are contracts and judgements.
\end{abstract}

\section{Introduction}

The relatively large number of publications on legal language shows that there is a growing interest in this special domain. There are several issues which are of importance when examining legal language. One common complaint is that in the interest of precision, written legal texts become obfuscated, and there are many writers who are concerned with improving the readability of these texts (Daum 1980, Fuchs-Khakhar 1987, Radtke 1981, Schönherr/Barfuß 1985). Other researchers are concerned with the role of legal language in society (Buße 1992), and especially with the linguistic sources of inequity (Bhatia 1993, Gibbons 1994, Kniffka 1990). Both of these approaches, however, must be based on a sound description of existing language use, and it is this area to which this paper is intended to contribute.

Existing research in this field has been based mainly on qualitative methods and intuitive judgements. Analyses have generally been carried out on the basis of amounts of data too small for valid generalisations to be made, and in the few cases where legal language is described on the basis of frequency analyses using larger amounts of data, the data are mostly drawn from only one text type (e.g. statutes as in Matzke

\footnotetext{
* Jane Norre Nielsen

* Anne Wichmann

Department of Cultural Studies

University of Central Lancashire

Fylde Building

GB-Preston PRI $2 H E$
} 
1988) ${ }^{1}$. The results therefore cannot be said to represent legal language as a whole.

The purpose of our study is neither to defend nor to criticise the language used in legal texts, but merely to describe linguistic features found in different types of legal writing and examine the reasons for their use. A possible outcome of this may be that a specific linguistic phenomenon which is normally claimed to be characteristic of legal language, is not only characteristic of the language in this domain but also of e.g. technical language, or that it is characteristic of one type of legal writing but not another.

The reason why we have chosen to investigate the expression of obligation in German and English legal texts is that the texts which are the basis of our research all belong to the field of contract law. Thus they are either contracts, i.e. texts which lay down the obligations - and rights - of the parties to the contract, or they are texts which are concerned with contracts in different ways (e.g. the statutes within contract law, textbooks on contract law, judgements in the case of breach of contract and so on).

The analysis of the expression of obligation that we have carried out in this study is based on 50,000 words of German contracts and judgements, and 50,000 words of English contracts and judgements. The English data are a subset of a corpus of 1 million words of English contract law texts, which - together with a French and a Danish contract law corpus - has been compiled at the Business Schools in Aarhus and Copenhagen. The German data will form part of a corpus of 1 million words of German text pertaining to contract law, which is currently being compiled at the University of Central Lancashire in Preston.

As the German contract law corpus is intended to complement the existing contract law corpora, it is being compiled according to the same principles governing the existing corpora (see Dyrberg et al 1991) and thus consists of six different text types relevant to the field of contract law: 1) statutes, rules, and regulations, 2) travaux préparatoires, 3) judgements, 4) contracts, 5) extracts from legal textbooks, and 6) articles in law journals.

1 An example of a study, however, based on a large amount of data from four different typs of legal writing is Lauridsen, K. M. (1992): The Meaning and Use of the Modals CAN and MAY in English Contract Law Texts, in: Hermes, Journal of Linguistics 9, pp. 43-64. 


\section{The expression of obligation}

An obligation may be expressed in various grammatical and lexical ways, but this study limits itself to the investigation of grammatical ways of expressing an obligation, particularly through the use of modal verbs. Based on general observation of how obligation is generally expressed, one would expect to find many occurrences of must in the English texts and of müssen and sollen in the German texts.

One way of investigating the frequency of modal verbs in the selected texts is to look at the rank order of these among the other word forms found in the texts. Thus table 1 shows the rank order of modal verbs among the 200 most frequent word forms in English contracts and judgements. This is compared with the rank order of modal verbs among the 200 most frequent word forms in the Birmingham corpus (Renouf 1988: 149), which may be described as a collection of general, non-specialised texts.

In table 2 we see the rank order of modal verbs in the German data. This analysis was restricted to legal text, as a corpus of non-specialised written German was not available for comparison. 
From table 1 (the English data) it is evident that the text type "contracts" is marked in two ways. Firstly, fewer types of modal verbs occur among the 200 most frequent word forms in this text type than in both the judgements and the Birmingham Corpus (viz. only shall, will, may, and must). Secondly, of particular interest for the expression of obligation, it is striking that shall is the most frequently used modal verb and seventh most frequent word form overall in the English contracts, whereas it is ranked only as number 156 in the analysed judgements and is not found at all among the 200 most frequent word forms in the Birmingham Corpus. Must, however, which we expected to occur frequently, has a relatively low rank in all three categories, namely 106 in the judgements, 101 in the contracts, and 141 in the Birmingham Corpus. It appears from this, that the text type judgements does not differ distinctively from general language in the frequency of modal verbs.

The striking difference regarding the frequency and use of modal verbs in the two text types "contracts" and "judgements" is, of course, to some extent a consequence of the difference in the nature and purpose of these text types. The main function of a contract is to express legal stipulations and requirements in a given context. The function of a judgement, on the other hand, is not only to express the judge's decision, but also to give an account of the case. There is therefore only a small section of the text which could be claimed as "performative", the remainder being for the most "narrative". This would account for a greater variety regarding the use of modal verbs - similar to general language - in the judgements than in the contracts.

This difference in text functions between contracts and judgements is not reflected to the same extent by modal verbs in the German texts (table 2). In both text types only three modal verbs are found among the 200 most frequent word forms, and two of these are merely two forms 
of the same modal verb, namely können, which is used to express a possibility. Forms of müssen or sollen, which we expected to occur frequently, are only found in the judgements, where $m u \beta$ is ranked as 149 . However, a closer study of the examples with muß (müssen) in the judgements shows that in most cases these express a logical necessity and not an obligation. Darf, which is the only modal verb found among the 200 most frequent word forms in the contracts, apart from kann/können, is used as an expression of a right, or if it is negated, which is mostly the case in this data, as an expression of a prohibition, i.e. an obligation not to do something.

It should be pointed out, however, that it is difficult to investigate the rank of modal verbs among the word forms found in German texts - and especially to make the comparison with English. Firstly, each modal verb has several forms, e.g. können, kann, kannst, which each correspond to the English can. Secondly, the most common grammatical words, the and $a$, an in English have many more counterparts in German, namely der, den, des, dem, die, das = the and ein, einen, eines, einem, eine, einer $=a$, an, which makes frequency lists on the basis of word forms only, difficult to compare across languages.

With this reservation in mind, we will now examine the relative frequency of modal verbs in English and German judgements and contracts expressed as a percentage of the total number of words in these texts. 
Fig. 1 presents evidence from the English data ${ }^{2}$. It shows that would, should, can, and could are the most frequent modal verbs in the English judgements, whereas they are rather infrequent in the English contracts. They are followed by may, must, will, and shall, which are relatively rare in the judgements but are the most frequently used modal verbs in the contracts. Finally, might and ought to are very infrequent in the judgements, and they do not occur in the contracts at all.

From this ranking of the modal verbs in the English texts it appears that the frequency order of occurrence in contracts is virtually reversed in the judgements, i.e. what is frequent in one text type is infrequent in the other. In fact none of the modal verbs in the judgements are used particularly more frequently than the others - perhaps with the exception of would - whereas in the contracts, one modal verb, namely shall, is used remarkably more frequently than the others. This is evidence of the restricted use of shall with 3rd person subject (to express legal requirements), referred to in Quirk et al 1985, 229 (4.58 n (c)).

Turning now to the German data, if we look at figure 2, which shows the relative frequency of modal verbs in the German judgements and

2 In fig. 1, as well as 2, the modal verbs are listed in the rank order in which they occur in the judgements. 
contracts, we can conclude that können is the most frequently used modal verb in both text types. In fact, apart from dürfen, which is the second most frequently used modal verb in the contracts, the modal verbs occur in the same rank order in the contracts as in the judgements. Furthermore, it is striking that, although the various morphological forms of each of the modal verbs have been added together, the two modal verbs which we expected to occur frequently, namely müssen and sollen, are relatively infrequent in both the judgements and the contracts - they represent only $0.09 \%$ of the total number of words.

Since it is central to contracts - and to the performative part of judgements - to express obligation, it is clear that this must be expressed in some other way in the German texts. In the following we shall therefore seek to discover how an obligation is expressed in German contracts and judgements. It was pointed out at the outset, that this study is limited to an investigation of grammatical forms, and we shall thus ignore the fact that an obligation may be expresed lexically, e.g. by using a verb like (sich) verpflichten (to be obliged to), or pragmatically by simply making a statement (often using werden).

It should here be mentioned, however, that some scholars argue that werden can be a modal verb as in,

1 Der Käufer wird das Geld bezahlen (The buyer will pay the money)

Clearly the verb phrase wird bezahlen has a modal meaning in the above example, in that it is used to express an obligation, but we would argue that this is not sufficient to justify the classification of werden as a modal verb. Nonetheless, the use of werden as an auxiliary verb to express modal meaning would, of course, have to be included in a more exhaustive study of the expression of obligation in German legal texts.

\section{Expressing modality with sein/haben+zu+infinitive and to have to/to be to}

Another way of expressing an obligation grammatically in German is to use a construction consisting of sein (to be) or haben (to have) followed by $z u$ and an infinitive. This construction corresponds - at least at word level - to the English construction consisting of be or have followed by to and an infinitive or a past participle, in the following way: 
2 Das Geld ist (vom Käufer) zu zahlen

The money is to be paid (by the buyer)

The money has to be paid (by the buyer)

3 Der Käufer hat das Geld zu zahlen

The buyer has to pay the money

The buyer is to pay the money

In German grammars the construction of either sein or haben with $z u$ and an infinitive is generally referred to as "the modal infinitive" 3 , as the construction with sein expresses a possibility, a permission, a necessity, or an obligation, and the construction with haben a necessity or an obligation. Either sein $+z u+$ infinitive or haben $+z u+$ infinitive may thus be used instead of a construction with the modal verbs müssen and sollen, whereas only the construction with sein can replace the modal verbs dürfen and können.

It follows from the above that both the sein-construction and the haben-construction may be used as an expression of obligation. However, they differ from one another in that the latter always has an active meaning, whereas the former is generally considered to have a passive meaning (Gelhaus 1977: 390) ${ }^{4}$.

3 Thus e.g. Brinkmann (1971: 363ff) and Gelhaus (1977) use the term "der modale Infinitiv".

4 Brinker (1969: 29), however, argues that this is not necessarily the case. 
The relative frequency of the occurrence of the constructions with sein or haben with zu and an infinitive and of constructions with to have to or to be to in German and English judgements and contracts, expressed as a percentage of the total number of words, is shown in fig. 3 .

If we look at the first category in figure 3, namely the judgements, it is evident that the construction sein $+z u+$ infinitive is very frequent in the German judgements, whereas the construction haben+zu+infinitive is less frequent in these texts. However, neither to have to nor to be to is very frequent in the English judgements. In the second category, the contracts, the difference between German and English is even more marked. Thus both sein $+z u+$ infinitive and haben $+z u+$ infinitive are very frequent in the German contracts ${ }^{5}$, whereas in the English contracts there is only one example of to have to, and to be to does not occur at all.

From figure 3 we can thus conclude that whereas a construction of sein/haben $+z u+$ infinitive is frequently used in the German texts, and especially in the contracts, the corresponding construction of to be/have to is very infrequent in the English texts, and again especially in the contracts.

This means that although "ist schriftlich zu begründen" in example 4 a could be translated as "is/has to be in writing", in a legal text we are more likely to find a phrase with shall as in example $4 \mathrm{~b}$ (this, as the other examples here, is in fact a genuine example from the corpus data), especially in contracts. Likewise, "hat zu informieren" in example 5a could be translated as "has/is to inform". However, in authentic texts, and especially in contracts, we are more likely to find a phrase with shall, as in example 5b.

4 (a) Der Schiedsspruch ist schriftlich zu begründen...

(b) All notices ... shall be in writing...

5 (a) Die Firma hat den Factor unverzüglich zu informieren...

(b) The owner ... shall inform the Escrow Agent...

5 We have in the present study not investigated the relative frequency of each of the modal meanings of the sein-construction. However, a closer study of some of the analysed texts shows that in the judgements the sein-construction expresses mainly a (logical) necessity, whereas in the contracts it almost exclusively expresses an obligation. 


\section{Conclusion}

It appears from this study of the expressions of obligation in English and German judgements and contracts, that a construction of sein/ haben $+z u+$ infinitive in German contracts corresponds to shall in English contracts as an expression of obligation. The use of werden, and of lexical items such as verpflichten in this context has not yet been investigated. It remains to be seen to what extent the obligations inherent in legal contracts are expressed by these or other means.

\section{Bibliography}

Bhatia, V. K.(1993): Analysing Genre. Language Use in Professional Settings, LondonNew York: Longman.

Brinker, K. (1969): Zur Funktion der Fügung sein+zu+Infinitiv in der deutschen Gegenwartssprache. In: Engel, U./P. Grebe (Hrsg.): Neue Beiträge zur deutschen Grammatik. Hugo Moser zum 60. Geburtstag gewidmet, Mannheim, pp. 23-33.

Brinkmann, H. (1971): Die deutsche Sprache. Gestalt und Leistung. Düsseldorf, 2. Auflage.

Busse, D. (1992): Recht als Text. Linguistische Untersuchungen zur Arbeit mit Sprache in einer gesellschaftlichen Institution. Tübingen: Max Niemeyer Verlag.

Daum, Ulrich (Bearb.) (1980): Fingerzeige für die Gesetzes- und Amtssprache, hg. v. der Gesellschaft für deutsche Sprache im Einvernehmen mit dem Bundesminister des Innern, 10. Aufl., Wiesbaden.

Dyrberg, Gunhild et al (1991): Oprettelse af fagsproglige tekstkorpora: engelsk-franskdansk juridisk sprog (aftaleret). In: Ark nr. 60, København.

Fuchs-Khakhar, Christine (1987): Die Verwaltungssprache zwischen dem Anspruch auf Fachsprachlichkeit und Verständlichkeit. Tübingen: Stauffenburg Verlag.

Gelhaus, H. (1977): Der modale Infinitiv. Mit einem dokumentarischen Anhang über die im gegenwärtigen Schriftdeutsch gebräuchlichen "bar"-Ableitungen. Tübingen: Gunter Narr Verlag.

Gibbons, J. (ed.) (1994): Language and the Law. London-New York: Longman.

Kniffka, H. (Hrsg.) (1990): Texte zur Theorie und Praxis forensischer Linguistik. Tübingen.

Lauridsen, Karen M. (1992): The Meaning and Use of the Modals CAN and MAY in English Contract Law Texts. In: Hermes 9-1992, pp. 43-64, Århus.

Matzke, B. (1988): Die Modalität der Fügung "sein+zu+Infinitiv" in juristischen Texten. In: Deutsch als Fremdsprache 2, pp. 72-74.

Quirk, R./S. Greenbaum/G. Leech/J. Svartvik (1985): A Comprehensive Grammar of the English Language. London-New York: Longman. 
Radtke, J. (1981): Der öffentliche Sprachgebrauch. Band II : Die Sprache des Rechts und der Verwaltung. Stuttgart: Ernst Klett.

Renouf, A. (1988): A lexical syllabus for language learning. In: Carter/McCarthy: Vocabulary and Language Teaching. London-New York: Longman.

Schönherr, F./W. Barfuß (Hg.) (1985): Sprache und Recht. Aufsätze und Vorträge. Wien. 